UNIO - EU Law Jounal. Vol. 2, No. 2, June 2016, pp 140-154.

®2016 Centre of Studies in European Union Law

School of Law - University of Minho

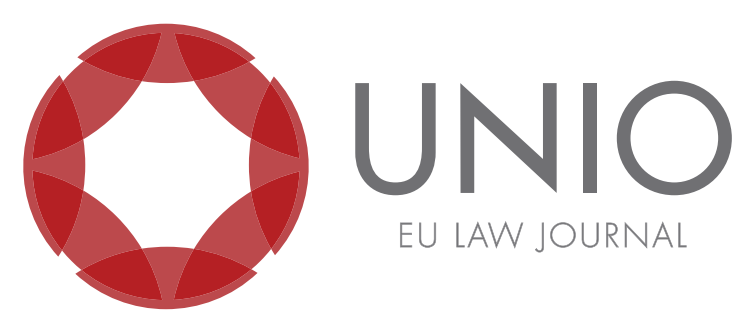

\title{
The emerging culture of EU citizenship as "citizenship of rights" and the legal nature of the EU polity
}

\author{
Alessandra Silveira* \\ Claudia McKenny Engström**
}

ABSTRACT: The current European crisis shows a crucial disjunction between the expectations of EU citizens and the institutional forms of political integration available to them. The crisis imposes challenges to the EU integration process, which sees its legitimacy questioned, above all in the eyes of the citizens of Member States undergoing intervention, who live with harsh restrictions and low expectations of improvement. EU citizens have never been so attentive to the developments of the EU integration - as testifies the rejection demonstrated in May 2014 elections to EU Parliament, now counting over 100 anti-EU voices. In this context, it is important to scrutinize whether the developing of an EU citizenship as "citizenship of rights" could perform some role in this scenario, putting it into perspective in order to grasp its effects on the legal nature of the EU polity. The status of EU citizenship is constructed around the paradigm of individual rights. Being an EU citizen basically means one is the holder of rights protected by the EU legal order - especially fundamental rights. Therefore, it is important to know to what extent the culture of rights has been strengthened by the change legal status of the Charter of Fundamental Rights of the European Union (CFREU) following the entry into force of the Lisbon Treaty in December 2009. In short, the text aims at knowing in which measure the fundamental rights dynamics in times of crisis affect the EU integration process itself.

KEYWORDS: crisis - EU citizenship - fundamental rights - citizenship of rights - EU polity.

\footnotetext{
*Professor of University of Minho (Braga/Portugal) and Jean Monnet Chair in EU law.

**Communication Officer at the Lifelong Learning Platform, Dottore Magistrale in Law and Politics of EU integration.

1 This question directed some of the questions of the Questionnaire General Topic 2 - Union citizenship: development, impact and challenges, The XXVI FIDE Congress (Copenhagen, 2014).
} 


\section{Crossing the border from national to EU citizenship ${ }^{2}$}

Citizenship rights were always a result of individuals belonging to a particular political community. But EU citizenship, unlike national citizenship, does not presuppose the polity to which the citizen belongs - it creates that community through the exercise of rights. ${ }^{3}$ In the context of EU integration, the debate on citizenship arose in the 70's aiming to provide a set of civil, political and social rights to the nationals of a Member State acting upon their economic freedoms in another Member State, allowing them to be on equal terms with the nationals of the host Member State, and in this way promoting an equal standard of the legal positions of nationals of Member States. Hence, EU citizenship was always connected with the principle of nationals' equality in the different Member States - they would benefit from the rights and be subject to the duties set out in the Treaties. ${ }^{4}$ And this idea of a community of rights and duties (established by the EU and not by a singular Member State) promotes a sense of belonging to the Union among individuals. That is, EU citizenship is built and developed through the exercise of rights - and for this the Court of Justice of the European Union (ECJ) case law, issued at the request for preliminary rulings by national courts, has weighed immensely.

Since the notion of citizenship was traditionally connected with preserving Nation-States (distinguishing between "we" and the "other"), the recognition of EU citizenship through the Maastricht Treaty (Treaty of the European Union - TEU, 1992) raised the following questions: 1) «what kind of political community could be created beyond the Nation-State?», 2) «what relationship would it have with national political communities?», 3) «who would its members be and what rights would they have?» - all issues that are at the core of European integration as a political project, and are still a major concern nowadays. ${ }^{5}$ In fact, because EU citizenship does not serve to preserve Nation-States and refers to a large number of nationalities, it could not have - and it does not have - the same nature as national citizenship, being original and essentially an inclusive citizenship. ${ }^{6}$ In his Opinion in the Rottmann case, ${ }^{7}$

\footnotetext{
${ }^{2}$ This text was developed following Alessandra Silveira's presentation at the international conference "Shattering Iberia - cultural responses to an ongoing crisis", organized by UC Berkeley Department of Spanish and Portuguese, University of California - Berkeley, USA, March, 5, 2014. It appeared as a result of a reflection on the theme highlighted in Claudia McKenny Engström's Master thesis "The evolution of Union citizenship in ECJ case law. A contribution to the definition of the legal nature of the European Union”, directed by Alessandra Silveira and presented at the Université Montpellier 1, Universitat Autònoma de Barcelona, Università Degli Studi di Milano and Uniwersytet Szczecinski (Joint European Master "Law and Policies of European Integration: European Constitutional Law and Multilevel Constitutionalism') on July, 2014.

${ }^{3}$ See E. Poptcheva, Multilevel citizenship. The right to consular protection of EU citizens abroad, Peter Lang, 2014, 87-88.

${ }^{4}$ As set out in article 9 TEU and article 20(2) TFEU.

${ }^{5}$ Such questions were raised by D. Chalmers, C. Hadjiemmanuil, G. Monti and A. Tomkins, European Union Law. Text and materials, Cambridge University Press, 2006, 561-562, where one reads: "the debate surrounding citizenship concerns the nature of political community».

${ }^{6}$ About the ideas of inclusion and exclusion in the context of European citizenship see C. Barnard, The substantive law of the EU. The four freedoms, Oxford University Press, 2007, 411. For a perspective of EU citizenship as a «constructive, transformation and multiple identity» see A. Verhoeven, The European Union in search of a democratic and constitutional theory, Kluwer Law International, 2002, 168 and ff. In regards to the connection between citizenship and the «constitutional framework» of the Union and its growth as a political community see J. Shaw, Law of the European Union, Palgrave Law Masters, 2000, 381 and ff.

${ }^{7}$ Judgment Rottmann, Case C-135/08, March 2, 2010.
} 
Advocate-General (A.G.) Poiares Maduro tries, in some way, to address the questions referred above on the relationship between nationality of a Member State and EU citizenship. As explained by Poiares Maduro, EU citizenship assumes a Member State nationality, ${ }^{8}$ but is also a legal and political concept independent of the concept of nationality, in the sense that it presumes the existence of a political connection between EU citizens, although it is not a relationship of belonging to a people. This political connection unites the European peoples and results from the reciprocal commitment of opening their political communities to other European citizens and building a new form of civic and political solidarity on a European scale. As has been pointed out - we are reminded by Poiares Maduro referring to Joseph Weiler -, the radically innovative character of the concept of EU citizenship lies in the fact that «the Union belongs to, is composed of, citizens who by definition do not share the same nationality». ${ }^{9}$ Hence, EU citizenship is not limited by a particular nationality and is the platform for a new political sphere from where rights and duties stipulated by the EU - and not from a Member State - emerge. ${ }^{10}$

It was not for another reason that the debate about EU citizenship developed in parallel (and ended up being confused) with the discussion of the protection of the fundamental rights within the Union: if European citizens are the holders of rights set forth in the Treaties, they are also holders of fundamental rights recognised by the EU legal system - whether they exercise economic freedoms or not. Art. 20 (2) of Treaty of Functioning of the European Union (TFEU) provides that EU citizens shall enjoy the rights and be subject to the duties provided for in the Treaties. A non-restrictive interpretation of that provision suggests that EU citizenship not only includes the rights that traditionally have been attached to $\mathrm{it}^{11}$ (as the right to vote in European Parliament elections or to apply to the European Ombudsman) but also relates it to the protection of fundamental rights. So, being an EU citizen basically means one is the holder of rights protected by the European legal system - maxime fundamental rights. The close connection between EU citizenship and the protection of fundamental rights was inferred by the Advocates General of the ECJ even before its formal protection in the Treaties ${ }^{12}$ - that is visible in A.G. Jacobs' Opinion in the Christos Konstantinidis case. ${ }^{13}$ Faced with the question of knowing if a person who acts upon their freedom of movement could, in the terms of Community Law at the time, oppose the harmful treatment of their fundamental rights, the A.G.

\footnotetext{
${ }^{8}$ As stated by the EU Treaties (Art.9 TUE) is EU citizen who has the nationality of a Member State. Therefore, «Union citizenship is a legal status stablished by the EU Treaties, which is additional to national citizenship (and dependent upon it)». See N. Shuibhne, J. Shaw, "General report", in Union citizenship: development, impact and challenges. The XXVI FIDE Congress in Copenhagen 2014, U. Neergaard, C. Jacqueson, N. Holst-Christensen (eds.), Congress Publications, Vol. 2, DJOF Publishing, 2014, 65.

${ }^{9}$ J. Weiler, The Constitution of Europe (Cambridge University Press, 1999), 344.

${ }^{10}$ For all, Judgment Rottmann, Case C-135/08, September 30, 2009, A.G. Opinion, para. 23. With a common position see C. Barnard, The substantive law of the EU. The four freedoms, Oxford University Press, 2007, 458, where one reads: «European citizenship does allow individuals a multiplicity of associative relations based on manifold economic, social, cultural, scholarly, and even political activities, irrespective of the traditional territorial boundaries of the European nation States, without binding individuals to a particular nationality».

${ }^{11}$ Subparagraphs a), b), c) and d) of the same Art. 20 (2) of TFEU.

${ }^{12}$ For this see C. Closa Montero, "Martínez Sala and Baumbast: an institutionalist analysis", in The past and future of EU Law, M. Poiares Maduro/L. Azoulai (eds), Hart Publishing, 2010, 395.

${ }^{13}$ Judgment Konstantinidis, Case C-168/91, December 9, 1992, A.G. Opinion, para. 42 and 46.
} 
supported the right to assert a «civis europaens sum» and claim this condition to oppose any violation in a person's fundamental rights.

Therefore, mobility does not boil down to indicators of economic competitiveness and development - it implies the exercise of fundamental rights: ${ }^{14}$ «When citizens move, they do so as human beings, not as robots. They fall in love, marry and have families». ${ }^{15}$ So, the idea that EU citizenship would allow access to the EU standard of fundamental rights' protection would be revisited six years later by the same A.G. Jacobs in the Bickel and Franz case, ${ }^{16}$ where he claims that EU citizenship «implies a community of rights and duties that unite EU citizens by a common connection that is transcendent to the issue of Member State nationalitys. ${ }^{17}$ The idea caused reservations under the fundamental rights' theory: first because EU citizenship was originally conceived as a migrant citizenship, associated with the freedom of movement, and the fundamental rights should not depend on personal mobility; second, because EU citizenship was reserved to Member State nationals, thus excluding third country nationals from the protection of fundamental rights granted by the EU. For those reasons, EU citizenship should not be mixed up and confused with the protection of fundamental rights. ${ }^{18}$ However, convergence was inevitable. The objections were suppressed by the evolution of ECJ case law in relation to the expansion of the scope of application of EU citizenship, as well by the progressive uniformity between nationals and foreigners concerning the enjoyment of fundamental rights present in the EU Member States' legal orders - i.e., under Member-States legal orders and under the EU legal order the fundamental rights of citizens tend to be rights of all.

So, ever since Maastricht Treaty, at least, European citizenship and European identity were seen as pivotal to the process of integration: that is, they were used as concepts overarching a certain pluralism that could be accommodated as internal and navigated through subsidiarity. But the current crisis imposes challenges to the EU integration process which sees its' legitimacy questioned, above all in the eyes of the citizens of Member States undergoing intervention, who live with harsh restrictions and low expectations of improvement. So what is the status today of EU citizenship in the context of the resurfacing of the local, and the resurgence of some hostility between nations across the north/south divide of the Eurozone? EU citizens have never been so attentive to the developments of the EU integration. And because of that, the most serious mistake of the majority of citizenship and fundamental rights actual analysis is that it tends to underestimate the systemic transformative potential of the crisis.

As recently explain Niamh Nic Shuibhne and Jo Shaw, «As both a status and an ideal, Union citizenship stands at the interface of integration and constitutionalism, and is a barometer for key trends and influences at the current crossroads between the Member States and the European Union». ${ }^{19}$ On its turn, the current crisis

\footnotetext{
${ }^{14}$ In this sense, see S. Weatherill, "Cases and materials on EU Law", chapter 15 (European citizenship within an area of freedom, security, and justice), Oxford University Press, 2007, 477 and ff.

${ }^{15}$ Judgment Zambrano, Case C-34/09, September 30, 2010, A.G. Opinion, para. 128.

${ }^{16}$ Judgment Bickel and Fran₹, Case C-274/96, November 24, 1998.

${ }^{17}$ Judgment Bickel and Fran₹, Case C-274/96, March 19, 1998, A.G. Opinion, para. 23.

${ }^{18}$ In this sense, see D. Chalmers, C. Hadjiemmanuil, G. Monti, A. Tomkins, European Union Law. Text and materials, Cambridge University Press, 2006, 561; A. Verhoeven, The European Union in search of a democratic and constitutional theory, Kluwer Law International, 2002, 185-187.

${ }^{19}$ N. Shuibhne, J. Shaw, "General report", in Union citizenship: development, impact and challenges. The
} 
questions the relation of national politics to European politics and puts the question of what principles and values are substantial enough to underpin a conception of the common good. Therefore, the main question in this context is whether the crisis shows some crucial disjunction between the expectations of EU citizens and the institutional forms of political integration available to them - and if the developing of a broad notion of «citizenship of rights» could perform some role in this scenario. It is worth recalling that the political processes are broader and deeper than the formal institutions charged to regulate them. And the most crucial decisions relating the public life are not taken by parliaments - they are taken in a domain standardized by collective consciousness. ${ }^{20}$

\section{The gradual evolution of EU citizenship through the notion of movement}

As we said above, EU citizenship is strongly tied to the economic origins of the European integration. Therefore, the rules which applied to it followed the logic enshrined in the freedom of movement. Upon consecration of the status of citizen of the Union to all Member State nationals with the Maastricht Treaty, the CJEU soon seized the opportunity to disconnect this novel status from pure market considerations. Citizenship thus started to find its true meaning. ${ }^{21}$ However, it remained linked to its national origins, in the light of both procedural and substantial conditionality set by the idea of movement. But in its latest jurisprudence on citizenship matters - especially in the Rottmann ${ }^{22}$ and Zambrano ${ }^{23}$ cases - the CJEU has taken a step away from its traditional reasoning based on movement, allowing situations presenting no cross-border element or evident link with EU law aside from the status of citizen of the Union, to enter the scope of Union law, raising a debate on the scope of application of EU law.

«One of the most far reaching revolutions in case-law» ${ }^{24}$ was inaugurated in 2010 with the landmark decision delivered in the Rottmann case, followed one year later by the no less groundbreaking Zambrano ruling, in which the ECJ finds that deprivation of the enjoyment of the substance of rights conferred to Union citizens constitutes a link with Union law. These cases are revolutionary for two reasons: first, they entered the scope of EU law although they presented no cross-border element, neither physical nor normative; second, there was no link with EU law as both concerned matters under exclusive Member State competence, the rules on attribution and loss of nationality in Rottmann, and rules on immigration in Zambrano. Since EU law is not intended to be omnipresent, ${ }^{25}$ the cross-border logic was used

XXVI FIDE Congress in Copenhagen, 2014, U. Neergaard C., Jacqueson, N. Holst-Christensen (eds.), Congress Publications, Vol. 2, DJOF Publishing, 2014, 66.

${ }^{20}$ In this sense see C. Geertz, The interpretation of cultures, New York, Basic Books, 1973.

${ }^{21}$ To know how did one move from a market citizenship (based on economic freedoms), to a social citizenship (based on social rights), so that one could finally reach a republican citizenship (based on active participation and involvement) see C. Barnard, The substantive law of the EU. The four freedoms, Oxford University Press, 2007, 410.

22 Judgment Rottmann, Case C-135/08, March 2, 2010.

${ }^{23}$ Judgment Zambrano, Case C-34/09, March 8, 2011.

${ }^{24}$ D. Kochenov, "The present and future of Union citizenship. A bird's eye view of the legal debate", in Jean Monnet Working papers, NYU, 2012, http://centers.law.nyu.edu/jeanmonnet/ papers/12/documents/JMWP02Kochenov.pdf.

${ }^{25}$ Judgment Kremzow, Case C-299/95, May 29, 1997. 
by the ECJ in its delimitation of the scopes ratione materiae of the coexisting national and EU legal orders, the largely criticized downfall of which was the creation of reverse discriminations - or discrimination against one's own nationals, between the so-called static and migrant/mobile citizens, as we will see infra.

This is the essential issue in the Rottmann and Zambrano case law: is it necessary to move so that one can rely on the Treaties regarding citizenship and rights attached to it? Such uncertainty leads to an understanding of the problem of the so-called «purely internal situation» (which would not fall within the scope of EU law) and the way in which the ECJ has addressed the question (concerning the reverse discrimination that it brings). This problem was faced by A.G. Tesauro in the Lancry case, concerning the obstacles to the free movement of goods, people, services and capital limited to the territory of a single Member State. As he said: «An experienced lawyer will also notice the paradox of a single market in which barriers to trade between Portugal and Denmark are prohibited, whilst barriers to trade between Naples and Capri are immaterial». ${ }^{26}$ As A.G. Poiares Maduro explains in the Carbonati case, the expression «reverse discrimination» refers to the situations in which nationals of a Member-State who did not use their freedoms of movement find themselves in a less favourable legal situation than the nationals of other Member States who did exercise those freedoms. ${ }^{27}$

Therefore, the real question nowadays about EU citizenship is the urgent clarification of the scope of application of the fundamental rights in the European Union. It derives from ECJ case law, confirmed by Art. 51 of CFREU, that the fundamental rights protected by the EU legal order may be invoked when the measure at stake belongs to the material field of application of EU law. ${ }^{28}$ And the field of application of EU law is the one that derives from its competences, as stated in Art. 2 to 6 of TFEU. But from this provision results an uncomfortable difference in treatment between the so-called mobile citizens (who exercise their classic EU rights/economic freedoms and therefore benefit from the EU standard of fundamental rights' protection) on the one hand, and static citizens (who do not exercise economic freedoms, and for that reason do not benefit from the EU standard of fundamental rights' protection) on the other. The current EU standard of fundamental rights' protection seems incompatible with the phenomenon of «reverse discriminations». This phenomenon implies the differentiation of treatment, even in relation to the fundamental rights, between mobile and static citizens - and seems in contradiction towards Art. 18 TFEU, according to which discrimination based on nationality is prohibited.

That result would no longer be compatible with the actual context of a citizenship of rights and with the trend to match legal positions. It was predictable that the entry into force of the CFREU would cause such adjustments. However, the consequences of this new unfolding of fundamental rights in the European integration process are yet to be seen. Since the Zambrano case, the ECJ has been faced

\footnotetext{
${ }^{26}$ Judgment Lancry, Case C-363/93, June 28, 1994, A.G. Opinion, para. 28.

${ }^{27}$ Judgment Carbonati, Case C-72/03, May 6, 2004, A.G. Opinion, para. 55.

${ }^{28}$ See Judgment Klensch (Joined Cases 201/85 and 202/85) November 25, 1986, para. 10 and 11; Judgment Wachauf, Case 5/88, July 13, 1989, para. 22; Judgment Bostock, Case C-2/92, March 24, 1994, para. 16; Judgment Booker Aquaculture (Joined Cases C-20/00 and C-64/00) July 10, 2003, para. 68. It is firm ECJ jurisprudence that Member States must respect fundamental rights protected by EU law: 1) when applying EU law, 2) when temporarily derogating EU norms, 3) when transposing EU directives, 4) when adopting national measures of execution of European legislation, 5) when applying national law that entries in the material field of application of EU law.
} 
with the impact of fundamental rights (in particularly the protection of family life) in determining the meaning and the scope of EU citizenship as set out in the Art. 9 TEU and 20 TFEU. The ECJ was challenged to give the concept of EU citizenship a practical dimension in connection to the problem of fundamental rights' protection within the EU, i.e., admitting EU citizenship as a platform that allows a Member State national to gain access to the EU standard of fundamental rights' protection, avoiding, this way, the EU citizen to find fictitious or hypothetical connections with the economic rights to benefit from that legal protection. ${ }^{29}$

The Zambrano case law involved ascertaining if EU citizenship allows an ascending family member of an EU citizen (minor and static, i.e., that has never exercised an economic freedom) the right of residence in the Member State in which the child was born. The parents of this EU citizen (minor and static) are third country nationals, therefore the situation involves Member States' immigration competences and for this reason it apparently would not enter the scope of application of the EU law. Moreover, the ECJ held that Art. 20 TFEU «precludes a Member State from refusing a third country national upon whom his minor children, who are European Union citizens, are dependent, a right of residence in the Member State of residence and nationality of those children, and from refusing to grant a work permit to that third country national, in so far as such decisions deprive those children of the genuine enjoyment of the substance of the rights attaching to the status of European Union citizen» (emphasis added).

The uncertainty and some apparent lack of coherence in jurisprudence pertaining to EU citizenship have not spared doctrine from virulent criticism towards the ECJ as much as among itself, especially regarding recent case law. One side roots itself in a comfortable status quo following a conservative tradition, deploring the «drastic disrespect for written legal rules»; $;^{30}$ the other, claims to provide a reasoned analysis sometimes espousing «an unjustifiable extension of the EU's powers justified by the extremely important problems the Court has to deal with which requires a sympathetic understanding of the Court's attempts to engage the problems in a constructive manner and especially in the absence of any clear alternative». ${ }^{31}$ If it can be argued that the scope ratione materiae has not been extended, these cases are nonetheless the symbol of the full deployment of EU citizenship's capacity.

They are bringing the EU legal system face to face with the meaning and scope of EU citizenship: does it serve only to support the freedom of movement of economically active citizens, or is it connected with a uniform set of rights and duties, typical of a Union based on the rule of law, in which fundamental rights perform an essential role? ${ }^{32}$ Since Union citizenship «can be seen as a microcosm of some of the key variables at play within the story of EU integration more generally», ${ }^{33}$ and it is «destined to be the fundamental status of nationals of the Member States», ${ }^{34}$ what are then the implications of a citizenship divorced from the idea of movement on the dynamics which animate the Union? And is it already time to move on? ${ }^{35}$

\footnotetext{
${ }^{29}$ See Judgment Zambrano, Case C-34/09, September 30, 2010, A. G. Opinion, para. 167.

${ }^{30}$ K. Hailbronner, D. Thym, "Comment to the Ruiz Zambrano case", in CMLR, 48, 2011.

${ }^{31}$ D. Kochenov, "A real European citizenship: a new jurisdiction test, a novel chapter in the development of the Union in Europe", in Columbia Journal of European Law, Vol. 18, 2011, 93.

${ }^{32}$ Judgment Zambrano, Case C-34/09, September 30, 2010, A. G. Opinion, para. 3.

${ }^{33} \mathrm{~J}$. Shaw, The transformation of citizenship in the European Union. Electoral rights and restructuring of the political space, Cambridge University Press, 2007.

${ }^{34}$ Judgment Rudy Grzelczyle, Case C-184/99, September 20, 2001, para. 31.

${ }^{35}$ Judgment Zambrano, Case C-34/09, September 30, 2010, A. G. Opinion, para. 139.
} 


\section{Realigning the condition of movement through the new condition of enjoyment of the substance of rights: a transformation in nature of EU citizenship}

It is not easy to identify all of the implications arising from this seminal ECJ case law which has emancipated EU citizenship from the constraints inherent in its free movement origins. ${ }^{36}$ Although these judgments constitute binding precedent, they are not yet ECJ settled case law, which advises us to wait for new developments, namely because the ECJ case law is reluctant to define the essential content of EU citizenship ${ }^{37}$ - and usually evolves through a succession of breakthroughs and setbacks. As is clear, «the resulting intervention of EU law in purely internal situations is a truly ground-breaking constitutional development» and in subsequent case law the ECJ «placed firm emphasis on the exceptional nature of that intervention, stressing a threshold of forced departure from the territory of the Union before the genuine enjoyment of the substance of the citizenship rights could be considered a risk». ${ }^{38}{ }^{39}$ So, the evolution at work regarding the cross-border conditionality thus calls for an assessment of the reasons and effects of purely internal situations in the cohabitating legal orders and an a contrario analysis of their disappearance. With these perspectives in mind, we can then move to measure the degree of integration as it is and what inputs its future might require.

\subsection{Measuring the effects of the disappearance of cross-border conditionality}

The condition of movement has two sides to it. Firstly, it can be justified as a way of containing the scope ratione materiae of EU law (3.1.1); secondly, it can be criticized for being a mere procedural requirement which hinders citizens from accessing the substance of EU law in spite of the fundamentality of their status (3.1.2). In both cases are revealed the constant tensions between rights and competences.

3. 1. 1. Purely internal situations or the manifestation of the principle of conferral of competences regulating the relation between Member States and EU

In this first scenario, purely internal situations draw the line between the two EU and national legal orders. Prohibiting Union from applying in wholly internal situations is tantamount to declaring EU law is not omnipresent, that it does not include all situations a citizen might find him or herself in because national and EU legal orders are distinct from each other, although they cohabitate in an intricate multi-level system. Purely internal situations, presenting no extraneous element in the absence of a cross-border link, have been said to be the emanation of the principle

\footnotetext{
${ }^{36}$ See K. Lenaerts, "Civis europaeus sum: from the cross-border link to the status of citizen of the Union" in Online Tournal on free movement of workers within the European Union, 3, 2011, 7, http:// ec.europa.eu/social $/$ main.jsp?catId=475\&langId=en\&furtherPubs=yes.

${ }^{37}$ See D. Kochenov, "EU citizenship. New questions in need of an answer", in Alessandra Silveira, Pedro Froufe, Mariana Canotilho (eds.), Citizenship and solidarity in the European Union - from the Charter of Fundamental Rights to the crisis, the state of the art, Peter Lang, Brussels, 2013. A. Wiesbrock, "Disentangling the 'Union citizenship puzzle'? The McCarthy case”, in European Law Review, 36, 2001, 862.

${ }^{38}$ N. Shuibhne, J. Shaw, "General report", in Union citizenship: development, impact and challenges. The XXVI FIDE Congress in Copenhagen 2014, U. Neergaard, C. Jacqueson, N. Holst-Christensen (eds.), Congress Publications, Vol. 2, DJOF Publishing, 2014, 141.

${ }^{39}$ See Judgment Dereci, Case C-256/11, November 11, 2011, para. 68.
} 
of conferral of competences. Because they are the expression of Member States' «power to regulate the factors of production by reference to policy objectives other than those recognized as legitimate by EU law», ${ }^{40}$ others have argued they enshrine the principle of subsidiarity. ${ }^{41}$

The most salient downfall of this approach, as we explain above, it is to be found in reverse discrimination. Reverse discriminations can be defined as situations in which a static citizen is «left in a worse position» than a migrant citizen, «even though in all other respects their circumstances may be similar or identical»; ${ }^{42}$ or as situations in which a Member State discriminates against his own nationals. ${ }^{43}$ These situations are the result of the interaction between EU and national law, between two coexisting legal orders. According to some, they are an aberration vis-à-vis EU citizenship, and the perfect illustration of the almost ludicrous juridical system designed to maintain a cross-border element supporting the concept of purely internal situations. When the Union inaugurated its own citizenship, the number of situations presenting a reverse discrimination considerably increased, since EU citizenship multiplied the possibilities of benefiting from protection under EU law from a ratione personae perspective, now including all Member State nationals. ${ }^{44}$

The principle which suffered the most from this new step in the EU integration was the principle of equality. Indeed, if such discriminations are tolerated in an internal market, where the one who does not participate in economic development could not pretend benefit from the same rights as the one who moved from one Member State to another in order to do so, working, providing services or selling goods for instance, a legal order which distinguishes itself from the international legal order in the place it grants people, making them subjects of law and establishing a citizenship, the Union not only places their rights at equal level with the ones recognized to States, but undeniably proclaims the will to move beyond its initial function as market. The direction pointing towards a political Union, fundamental rights and the principle of equality, indispensable to democracy, are needed more vividly than ever.

The first dimension of purely internal situations, as manifestation of the principle of conferral of competences, keeps national and EU scopes of law in separated boxes. In this frame, they are positive elements of distinction between substances of law. They reveal the different legal orders cohabitating within the EU legal system. ${ }^{45}$ However, their existence is also maintained thanks to the persistence

\footnotetext{
${ }^{40}$ C. Ritter, "Purely internal situations, reverse discrimination, Guimont, Drodzi and Article 234" (2006), quoted in K. Lenaerts, "Civis europaeus sum: from the cross-border link to the status of citizen of the Union", footnote 7.

${ }^{41}$ P. Oliver, "Some reflections on the scope of articles 28-30 TEC", 2006, quoted in K. Lenaerts, "Civis europaeus sum: from the cross-border link to the status of citizen of the Union", footnote 7. ${ }^{42}$ Judgment Zambrano, Case C-34/09, September 30, 2010, A. G. Opinion, para. 133.

${ }^{43}$ Judgment McCarthy, Case C-202/13, November 25, 2010, A.G. Opinion, para. 39. On this subject, see H. Schermers, D. Waelbroeck, Judicial protection in the European Union, Kluwer Law International, 2001, 92: «whenever a Member State gives a preferential treatment to the nationals of other Member States as opposed to its own nationals, this should also amount to a discrimination prohibited by the Treaty». And also «the Court may be prepared, under certain circumstances, to prohibit reversed discrimination if there is a sufficient relationship with the Community Law».

${ }^{44}$ D. Kochenov, "A real European citizenship: a new jurisdiction test, a novel chapter in the development of the Union in Europe", in Columbia Journal of European Law, Vol. 18, 2011, 72.

${ }^{45}$ See M. Poiares Maduro, "Constitutional pluralism as the theory of European constitutionalism", in Estudos em homenagem ao Prof. Doutor José Joaquim Gomes Canotilho, Vol. III, Coimbra Editora, 2012,
} 
of an intergovernmental logic allowing Member States to act as «sovereign», but to the detriment of citizens and consequently, the Union as a whole. Contemplating purely internal situations from a procedural angle offers the possibility to counter the negative effects on citizenship created by a positive regulation of competences between Member States and Union.

\subsubsection{Purely internal situations or a procedural obstacle between citizens and the Union}

Since «movement is enough to bring the situation within the scope of EU law», ${ }^{46}$ the condition of cross-border element may also be understood as a mere procedural obstacle hindering citizens from accessing the substance of EU legal corpus. In that scenario, when the cross-border conditionality is removed, «no national rules fall $a$ priori outside the scope of the Treaty». ${ }^{47}$ The litigations developed above ${ }^{48}$ are case in point of this extension operated by the Court into exclusive competences of the State thanks to an enlargement and even abstraction of the condition of movement. This evolution finds its source in the Court's commitment to protect the corpus of fundamental rights guaranteed in Europe - such as found in the EU legal order, through the general principles of law as well as the CFREU, but also in national constitutions and the European Convention of Human Rights,$-{ }^{49}$ underlying motives guiding the Court's extensive reasoning in matters of citizenship. ${ }^{50}$

If this is a legitimate aim, it is not without carrying its own consequences, as the extension of fundamental rights via the status of EU citizenship proportionately affects the integration process. In a nourished comparison with the making of the United States of America's Federation, Beaud ${ }^{51}$ warns us of the «centralizing» effects of the use of fundamental rights in Federation building. The federalizing process is discovered in its first phase when it «becomes competent in ensuring respect for the fundamental rights granted to its citizens». ${ }^{52}$ In this initial stage, the federal level intervenes in the life of its citizens via the federated entities, which explains why the famous «Slanghterhouse cases» ${ }^{53}$ was so violently received as carrying for objective «to fetter and to degrade the State governments by subjecting them to the control of the Congress». ${ }^{54}$ The second step is taken when the federal level effectively protects these rights and does so according to the principle of equality ${ }^{55}$ between citizens. ${ }^{56}$

453, where one reads: «we can conceive of the EU and national legal orders as autonomous but part of the same European legal system. For those practicing law in Europe, this European legal system implies a commitment to both legal orders and imposes an obligation to accommodate and integrate their respective claims».

${ }^{46}$ E. Spaventa, "Seeing the woods despite the trees? On the scope of Union citizenship and its constitutional effects", CMLR, 45, 2008, 14.

${ }^{47}$ E. Spaventa, idem.

${ }^{48}$ See point 2 .

${ }^{49}$ See Art.6 TEU and Preamble and Art.52 CFREU.

${ }^{50}$ J. Shaw, "Citizenship: contrasting dynamics at the interface of integration and constitutionalism", in EUI Working papers, RSCAS 2010/60, 2010, 6.

51 O. Beaud, "Droits de l'Homme et du citoyen et forme politique /Le cas particulier de la Fédération", in RUDH, 2004, 16-26.

${ }^{52}$ O. Beaud, idem.

${ }^{53}$ Supreme Court of the United States, Slanghterhouse Cases, 14th April 1873, 83 U.S 36.

${ }^{54}$ E. Zoller, Les Grands arrêts de la Cour supreme des Etats-Unis, coll. Droit fondamentalfundamental, Paris, PUF, 2000, 25.

${ }^{55}$ O. Beaud, "Droits de l'Homme et du citoyen et forme politique...", footnote 23.

${ }^{56}$ In the USA, this step was taken by the Supreme Court finally breaking away from the Dred Scott 
This is the point at which we stand now, when EU law applies directly to citizens despite the absence of movement. Granting protection to mobile as much as static citizens, thus «frontally contradicting the idea that States conserve in principle the exercise of their competences in situations presenting no extraneous element $\gg{ }^{57}$ the ECJ erases the borders between national and EU scopes of law.

Needless to say the members of the ECJ are well aware of the consequences a total removal of the condition of movement allowing direct application of fundamental rights would have on the nature of the Union, ${ }^{58}$ which constitutes a valid explanation for the step back operated in $M_{c} C a r t h y^{59}$ and following judgments. Access to rights depending on competences thus depending on political will, an attempt to deepen integration and ensure equal protection of fundamental rights to both mobile and static citizens, notwithstanding the absence of a link with EU law, needs to be supported by an «unequivocal political statement from the constituent powers of the EU». ${ }^{60}$ The cross-border conditionality illustrates the constant internal tensions faced by a EU born from movement. It seems necessary for the EU to find the equilibrium between competences guided by the idea of movement and rights governed by the principle of equality.

\section{The necessity of thinking the Union beyond movement}

We have seen the potential effects of the removal of the condition of movement on the nature of European integration, as well as the downfalls of maintaining the status quo. The reality of the EU shows in fact that an intermediate between compartmentalization and centralization is possible. This possibility is clearly expressed in the clarifications brought by the McCartby judgment, when the Court reaffirms that the absence of a cross-border element is not an obstacle for a situation to fall within the ambit of EU law, so long as can be brought back the proof of a link with EU law. In other words, even if the Court consents to remove the cross-border conditionality, establishing a link with EU law remains a necessity to afford protection under the EU legal order. Consequently, flexibility is brought to the compartments created by the differentiation between migrant and static citizens, and yet, Union law does not become omnipresent. In analyzing the results of this new method on the degree of European integration, and in fine, on the nature of the Union, one must then reason on the origins and essence of EU law which will help in keeping the balance between the different levels of exercise of public power (4.1). Nonetheless, even if the Union has not reached the stage of omnipresence, relieving citizens from a pure market logic reminds us of the urgency in establishing a vertical relationship between the EU and its citizens (4.2), a condition of the viability of a

decision which denied slaves, the quality of citizen, and who could therefore not expect protection from the Federal government or the Courts. Stating that the US Supreme Court had no competence in banning slavery, this case signed the beginning of the civil war, Dred Scott v. John F. A Stanford, 1857.

${ }^{57}$ E. Dubout, "Le défi de la délimitation du champ de la protection des droits fondamentaux par la Cour de Justice de l'Union Européenne », in European Journal of Legal Studies, Vol. 6, Issue 1, Spring/ Summer 2013, 5-23.

58 Judgment Zambrano, Case C-34/09, September 30, 2010, A. G. Opinion, para. 173. A.G. Sharpston concludes her Opinion to Zambrano by comparing such an approach with the «federalising effect of the American incorporation doctrine» which «would alter, in legal and political terms, the nature of fundamental rights under EU law».

${ }^{59}$ Judgment McCarthy, Case C-434/09, May 5, 2011.

${ }^{60}$ Judgment Zambrano, Case C-34/09, September 30, 2010, A. G. Opinion, para. 173. 
Union beyond movement which will equally impulse a new vitality to a legal order still highly dependent on stato-centrism.

\section{1. The necessity of clarifying competences for the benefit of rights}

With regard to the individual citizen, until 2010-2011, citizenship was either an exclusive competence of the Union in cases of mobile citizenship or an exclusive competence of the Member State in static wholly internal situations. In order to break the classic reasoning, A.G. Eleanor Sharpston places free movement rights neither in the sole hands of the Union nor the States, but in the domain of shared competences, ${ }^{61}$ thus rebalancing responsibilities between EU and Member States. Indeed, following an enlarged interpretation of EU citizenship, the risks of shattering the delimitation of scopes of law and areas of competence are high. However, in a restrictive interpretation, reverse discrimination inevitably appear and grow in number, which, she explains, is of course to the detriment of citizens, but also to the detriment of Member States, who are left with handling the deficiencies of the EU legal order. What's more, in both instances, citizens remain in a situation of legal uncertainty, since a definite choice of approach has not yet been taken by the Court. Keeping at the core of her argument that even the noble desire to ensure the highest protection of fundamental rights «must not lead to an usurpation of competences», ${ }^{62}$ A.G. Sharpston makes an original proposal in juridical methodology, all kept in the frame and context of the Union. The starting point of this new reasoning stems from the cohabitation of EU and national legal orders, made clear in the reference to the concept of «equivalent protection» of fundamental rights. ${ }^{63}$

This proposal could be resumed in the following terms: beyond the scope of Art. 51 (1) CFREU, Member States remain autonomous in relation of fundamental rights protection, as long as it can be presumed that they ensure the essence of the EU standard of fundamental rights. However, in case of systemic violation, this presumption is rebutted - and in such a case, individuals can rely on their status as EU citizens to seek redress before national courts. ${ }^{64}$ Such a proposition is in line with the idea that the Union constitutes a community of rights ${ }^{65}$ built on a multilevel constitutionalism: a community composed of Member States guaranteeing at national level rights it also protects within itself. When the citizen, by virtue of his or her European status, may seek protection before the ECJ to ensure protection of these rights, it is undeniable that EU citizenship is one of rights. This qualification presents a number of advantages. It keeps the concept within a functional ambit distinguishing it from nationality, thus protecting the national level and sticking to the principle that EU citizenship is not destined to replace national citizenship but rather completes it, albeit its fundamental vocation. However, the scope of protection of fundamental rights by EU law is still an issue, ${ }^{66}$ and reveals the discrepancy of a system in which competences are so difficult to attribute.

\footnotetext{
${ }^{61}$ Judgment Zambrano, Case C-34/09, September 30, 2010, A. G. Opinion, para. 130.

${ }^{62}$ Judgment Zambrano, Case C-34/09, September 30, 2010, A. G. Opinion, para. 162.

${ }^{63}$ E. Dubout, "Le défi de la délimitation du champ de la protection des droits fondamentaux par la Cour de Justice de l'Union Européenne”, in European Journal of Legal Studies, Vol. 6, Issue 1, Spring/ Summer 2013, 5-23.

${ }^{64}$ See A. von Bogdandy (et al.), "Reverse Solange - protecting the essence of fundamental rights against EU Member States", in Common Market Law Review, Vol. 49, 2012, 491.

${ }^{65}$ Judgment Les Verts, Case C-294/83, April 23, 1986.

${ }^{66}$ E. Dubout, "Le défi...".
} 


\subsection{Establishing a vertical relation between citizens and the EU: condition of viability of a Union beyond movement}

If the European integration in its political aspect commands a shift in thought beyond movement, a complete abandonment of the idea of movement is not either acceptable, since it would freeze the Union in a state of questionable legitimacy if a certain number of issues at its core are not tackled first. As much as we agree with the imperative of pulling Union citizenship away from the economic logic, we do not fully agree that movement be understood merely as a synonym of economic freedom. Indeed, Union citizenship was granted to Member States nationals by Treaty provisions thanks to the will of its fostering institutions. Its activation relying on the exercise of movement had two effects with regard to democracy. On the one hand, kept in the frame of the democratic institutions in the Member States, EU citizenship reinforced the Union as constellation of democracies. ${ }^{67}$ On the other hand, it distinguished itself from national citizenship by the crucial role it gave the European person in the European construct. Building bridges between Member States by choosing to move and reside freely elsewhere than in his or her country of nationality, the migrant citizen participated directly in creating the destiny of the Union. ${ }^{6}{ }^{8}$ By now including static citizens, has the Court not broken this bottom-up construction? Nonetheless, this argument needs to be put in its context, precisely in the light of the intensity of competences exercised by the Union and in fine, influencing the life of those who move as much as those who stay still.

This brings us to the final question on the vertical relation between the EU and its citizens, particularly important when the Union proclaims the autonomy of EU citizenship in a parallel effect as when it declared autonomy of EU law vis-àvis national and international legal orders. ${ }^{69}$ When the ECJ declared that the Union formed a new legal order on the grounds that it became part of national legal orders and created rights and obligations towards individuals, now recognized as EU citizens, it confirmed that the degree of integration based on the quantity and quality of the transfer of competences operated to the benefit of the Union removed it from the category of international organization. But the international legal order recognizes States as subjects of law, a fact which has a significant impact on the procedural and substantial democratic requirements to be respected. When a legal order also recognizes individuals as subjects of law, it multiplies the number of addressees of the norms its legal order produces and proportionally increases its diffusion in their lives. Thus gaining in weight, the necessity of submitting it to consent grows.

The crucial moment at which the Union stands now is the need to create its own vertical relation with the citizens it protects. The legal basis already exists in article

\footnotetext{
${ }^{67}$ See M. Poiares Maduro, "Constitutional pluralism as the theory of European constitutionalism", in Estudos em homenagem ao Prof. Doutor José Joaquim Gomes Canotilho, Vol. III, Coimbra Editora, 2012, 461, where the Author identifies three main sources of constitutional and democratic added value that the process of EU integration and EU law can bring: 1) promotes inclusiveness in national democracies by requiring national political processes to take into account out-of-state interests and open themselves to the nationals of other Member States; 2) allows national democracies to collectively regain control over transnational processes that evade their individual control; 3) contributes a form of self-imposed external constitutional discipline on national democracies, rationalizing national policies that have become path-dependent or captured by certain interests.

${ }^{68}$ As we have previously developed, this citizenship based on movement organised a person's right to be recognised by the host polity.

${ }^{69}$ Judgment Van Gend \& Loos, Case C-26/62, February 5, 1963.
} 
9 TEU, by which «In all its activities, the Union shall observe the principle of the equality of its citizens, who shall receive equal attention from its institutions, bodies, offices and agencies». This means, in terms of process, that the Union instead of moving forward stands at a point where its movement must stop and diffuse itself in all its levels to effectively reach citizens and create its own social interlocutor. Unfortunately, granting rights might prove insufficient to create a viable community as a whole. The concept of nationality developed in Nation States created a vertical relation between citizens and public power grounded on a sentiment of belonging, incarnated in the idea of identity. ${ }^{70}$ But this verticality may equally exist within the concept of citizenship, with the advantage of being objective where nationality is subjective. A citizenship based on the level of protection of rights thus presents itself as an interesting tool to build a vertical relation between EU citizens and EU institutions, although it is not without raising questions of its own. First of all, without a clarification of competences and scope of law, would it not lead to creating a dangerous situation of double standard? ${ }^{71}$ Second, does a citizenship of rights have the capacity to take into account the political dimension of citizenship, i.e., citizenship as right to political autonomy? ${ }^{\text {?2 }}$

Nonetheless, for a vertical relation to be one of dialogue and respect, it also needs obligations, not only top-bottom obligations of institutions towards citizens, but also of citizens vis-à-vis these institutions, because only then will it be able to determine whether it holds an independent «power of being loved» ${ }^{73}$ because it offers European citizens, if not something more, at least something else than national citizenship..$^{74}$ Departing from a philosophy based on movement, the Union, thanks to the pro-activeness of the ECJ, has shown its full respect to European citizens. But for this relationship to develop, it is urgent that the Union gains their respect. If it is possible to imagine a European social contract in the absence of a demos in the classic sense, namely due to the fact that «the term 'peoples', which is not defined, may have different meanings in the Member States and languages of the Union» ${ }^{75}$ the meaning of social contract on the other hand, does not change: because it is a contract, albeit social, it requires the presence of two parties, both endowed with rights and obligations. For this to happen, EU citizenship must step out of the courtroom and enter the political forum.

\section{By way of conclusion...}

If the crisis has brought some benefit it is that: Europeans are getting to know one another. A pleasant story could be very useful to show that. The granting of EU financial assistance to Portugal depended of the agreement of all Member States of the Eurozone - and Finland threatened to oppose it. So, a video was spontaneously posted on the internet, in a funny and nice tone, entitled «What the Finns need to know about

\footnotetext{
${ }^{70}$ See point 1.

${ }^{71}$ Joint concurring Opinion Rozakis, Tulkens, Botoucharova, Zagrebelsky and Garlicki to ECHR decision Bosphorus, n. ${ }^{\circ}$ 45036/98, June 30, 2005.

${ }^{72}$ See M. Benlolo-Carabot, Les fondements juridiques de la citoyenneté européenne, Coll. Thèses, Brulyant, 2007.

${ }^{73}$ E. Zoller, Aspects international de droit constitutionnel. Contribution à la théorie de la fédération d'Etats, R.C.A.D.I, t. 294, 2002, 152.

${ }^{74}$ Judgment Maria Teixeira, Case C-480/08, February 23, 2010. The Teixeira judgment is an example of the birth of a form of European solidarity.

${ }^{75}$ Judgment M. G. Eman et O. B. Sevinger, Case C-300/04 and C-145/04, September 12, 2006, para. 71.
} 
Portugal». ${ }^{76}$ The video lasts around 6 minutes and discloses information as diverse as: «Napoleon tried to conquer Portugal 3 times and failed»; «We divided the world in 2, with Spain, and we got the better part: Brazil»; «We have more mobile phones than inhabitants: $60 \%$ are NOKIA»; «Portugal was the first country in the world to abolish the death penalty»; «60\% of Americans think that Portugal is a province of Spain so do same Spaniards»; «In September 1999, nearly a million and half of Portuguese people manifested, forcing the Indonesian to leave East Timor territory», etc. And the video finished on a more serious note, with long queues images destined to collect donations and the following message: «But one of the largest volunteer campaigns ever in Portugal was in 1940. We collected tons of clothes and cereals to support another peripheral, poor and starving country. This country was Finland».

The quick response entitled «What the Portuguese need to know about Finland» ${ }^{77}$ adopted the same informative and nice tone - one of the facts was that a half-Finnish and half-Portuguese girl had won the «Finnish Idols Song Competition». The conclusion also brought a more serious note: «Here we could mock you on the difficult financial situation of Portugal. We don't, because our hearts and minds are with you. With love, Finland». The end of the story is known: the approval was granted. With the crisis, Portuguese and Finns finally realized this simple idea which directs any federative or multilevel system: everything that happens in Finland concerns Portugal and everything that happens in Portugal concerns Finland.

\footnotetext{
${ }^{76}$ https://www.youtube.com/watch?v =6tiXdDFSEIL.

${ }^{77}$ https://www.youtube.com/watch?v=MgVugxNZEQc.
} 